\title{
RANCANG BANGUN SISTEM INFORMASI PENJUALAN DENGAN METODOLOGI BERORIENTASI OBYEK (STUDI KASUS : PT. BANGSAWAN CYBERINDO)
}

\author{
Deni Kuswoyo \\ Program Studi Informatika, Universitas Indraprasta PGRI \\ E-Mail: denikuswoyo@gmail.com
}

\begin{abstract}
Abstrak
Dalam era globalisasi saat ini teknologi informasi dan komputer akan memegang peranyang sangat menentukan dalam persaingan bisnis. PT. Bangsawan Cyberindo merupakan perusahaan yang bergerak dalam bidangpenjualan barang dan jasa teknologi informasi. Saat ini sistem informasi penjualan yang digunakan masih belum memaksimalkan penggunaan komputer, sehingga masihterdapat kegiatan yang menggunakan pencatatan secara manual. Dengan masih adanyapencatatan secara manual membuat staf penjualan mengalami kesulitan dalam halpencatatan data penjualan barang yang kurang akurat, lambat, dan tidak lengkap sehinggamenimbulkan keterlambatan dalam pelaporan data penjualan barang. Selain dari itu prosesakuntansi belum dilakukan dengan baik, sehingga laporan-laporan yang menggambarkanlaporan keuangan yang di perlukan belum tersedia. Oleh sebab itu, melalui penulisan ini penulis mengajukan usulan dengan memanfaatkan berupa rancang bangun sistem informasipenjualan yang mencakup kegiatan penjualan pada PT.Bangsawan Cyberindo.Dengan adanya sistem informasi ini maka pencatatan data lebih mudah dan menunjang kelancaran dalam sistem informasi penjualan. Selain itu memudahkan proses pencetakanlaporan berdasarkan periode yang diinginkan sehingga dapat mengetahui informasi dengan mudah, cepat,akurat, dan meminimalkan kesalahan.Sistem dirancang dengan metodologi berorientasi obyek, dan diimplementasikan denganmenggunakan bahasa pemerograman Visual Studio 2005 dan MS Access sebagaibasis datanya.
\end{abstract}

Kata Kunci : Sistem Informasi Penjualan, Metodologi Berorientasi Obyek

\begin{abstract}
In the current era of globalization, information and computer technology has a decisive role in a business competition. PT. Bangsawan Cyberindo is a company engaged in the sale of goods and services of information technology. Currently, the sales information system used has not maximized the use of the computer yet that there are still many activities using manual recording system. This manual recording makes sales staff have difficulty in recording the goods selling data because the data acquired are less accurate, slow and incomplete, leading to delays in reporting goods selling data. Besides, the accounting process has not been well conducted, so that important reports describing financial statements are not available yet. Therefore, through this paper, the author proposes the utilization of design of sales information system covering sales activities in PT.Bangsawan Cyberindo. This information system makes the data recording easier and supports the smooth running of sales information system. Then, the system also eases the report printing process based on the expected periods so that the information can be easily, quickly and accurately found and the errors can be minimized. The system is designed adopting objectoriented methodology and is implemented using programming language Visual Studio 2005 and MS Access as its database.
\end{abstract}

Keywords : Sales Information System, Object-Oriented Methodology 


\section{Pendahuluan}

\section{Latar Belakang}

Dalam era globalisasi saat ini penggunaan komputer dalam dunia teknologi informasi mengalami perkembangan yang sangat pesat dan cepat hampir disetiap aspek kehidupan.Persaingan bisnis yang semakin ketat menuntut perusahaan untuk memperoleh informasi dengan cepat dan akurat.

PT. Bangsawan Cyberindo merupakan perusahaan yang bergerak dalam bidang jasa dan penjualan barang teknologi informasi. Dalam kegiatan penjualan barang belum menggunakan komputer secara keseluruhan yang saling terintegrasi antara satu dengan yang lainnya sebagai alat bantu kerja, sehingga dalam kegiatan sehari-hari masih terdapat kegiatan yang menggunakan pencatatan secara manual. Kekurangan cara manual dalam kegiatan penjualan barang adalah sering terdapatnya kesalahan dalam pencatatan dan banyaknya media kertas yang digunakan dalam kegiatannya.

Penjualan barang merupakan kegiatan yang memegang peran penting dalam proses bisnis suatu perusahaan khususnya perusahaan yang bergerak dalam bidang penyedia barang, karena penjualan barang merupakan salah satu proses bisnis transaksi.

Untuk memberikan peranan sistem yang lebih baik, maka diperlukan sebuah sistem informasi penjualan barang di dalam pengelolahannya sehingga dapat mengoptimalkan kinerja perusahaan dalam kegiatan penjualan barang. Dengan melihat permasalahan yang ada saat ini, maka penulis mencoba memberikan usulan dengan pokok bahasan "Rancangan Sistem Informasi Penjualan pada PT. Bangsawan Cyberindo dengan Metodologi Berorientasi Obyek".

\section{Tujuan Penelitian}

Tujuan penelitian adalah

1. Dengan penelitian ini diharapkan dapat memberikan suatu rancangan sistem untuk aplikasi sistem informasi penjualan sehingga dapat membantu staf penjualan dalam proses penjualan dengan cepat dan akurat.

2. Mengetahui sistem dan prosedur yang sedang berjalan dan dilaksanakan sebelumnya.

3. Mengevaluasi laporan-laporan yang dikerjakan oleh staf penjualan yang akan dilaporkan kepada pimpinan.

4. Mencoba memberi masukan kepada pimpinan agar sistem informasi penjualan dikomputerisasi sepenuhnya untuk mengurangi permasalahan yang selama ini masih secara manual.

\section{Manfaat Penelitian}

Manfaat penelitian adalah

1. Sistem komputerisasi sangat mendukung proses kerja seperti penyimpanan data sehingga dengan mudah dapat memberikan informasi yang dibutuhkan oleh staf penjualan pada saat dibutuhkan.

2. Dengan adanya sistem informasi ini akan membantu staf dalam proses transaksi penjualan karena pencatatan tidak perlu lagi dilakukan secara manual sehingga dapat dilakukan cepat, dan akurat.

3. Penyimpanan data dalam database memudahkan penyimpanan, pencarian, dan pemeliharaan data, sehingga tidak perlu lagi menyimpan data dalam media kertas yang mudah hilang dan rusak seperti pada sistem manual.

4. Menyediakan sistem informasi penjualan barang yang lebih baik, sehingga menghasilkan informasi yang lebih akurat dan dapat dimanfaatkan oleh pimpinan dalam pengambilan keputusan. 


\section{Tinjauan Pustaka}

\section{Konsep Dasar Sistem}

Mulyadi (2013) mendefinisikan sistem sebagai berikut : "Sistem adalah suatu jaringan prosedur yang dibuat menurut pola yang terpadu untuk melaksanakan kegiatan pokok perusahaan. Prosedur adalah suatu urutan kegiatan klerikal, biasanya melibatkan beberapa orang dalam satu departemen atau lebih yang dibuat untuk menjamin penanganan serta seragam transaksi perusahaan yang terjadi berulang-ulang."

Menurut Susanto (2013) dalam bukunya mendefinisikan sebagai berikut :“ Sistem adalah kumpulan/group dari sub sistem/bagian/komponenapapun baik phisik ataupun non phisik yang saling berhubungan satu samalain dan bekerja sama secara harmonis untuk mencapai satu tujuan tertentu".

Menurut Jogiyanto (2009) dalam bukunya mendefinisikan sebagai berikut :"Sistem dapat di definisikan dengan pendekatan prosedur dandengan pendekatan komponen ".

Suatu sistem mempunyai karakteristik atau sifat-sifat yang tertentu, yaitu mempunyai komponen-komponen (components), batas sistem (boundary),lingkungan luar sistem (environments), penghubung (interface), masukan (input), keluaran (output), pengolah (process), dan sasaran (objectives) atau tujuan (goal).

\section{Konsep Dasar Informasi}

Jogiyanto (2009) mengungkapkan : "Informasi adalah data yang diolah menjadi bentuk yang lebih berguna dan lebih berarti bagi yang menerimanya". Sumber dari informasi adalah data. Data merupakan bentuk jamak dari bentuk tunggal datum atau data-item. Data adalah kenyataan yang menggambarkan suatu kejadian-kejadian dan kesatuan nyata. Mulyanto (2009 ) mendefinisikan informasi sebagai berikut : "Informasi adalah data yang diolah menjadi bentuk yang lebihberguna dan lebih berarti bagi yang menerimanya, sedangkan datamerupakan sumber informasi yang menggambarkan suatu kejadian yang nyata ". Maka dapat disimpulkan bahwa informasi adalah data yang telah diolah atau diproses menjadi bentuk yang lebih berarti bagi penerimanya dan bermanfaat dalam mengambil keputusan saat ini dan mendatang. Akan tetapi informasi dapat menjadi data mentah bagi tingkat manajemen tertentu.

Data yang diolah melalui suatu model menjadi informasi, penerima kemudian menerima informasi tersebut, membuat suatu keputusan dan melakukan tindakan, yang berarti menghasilkan suatu tindakan yang lain yang akan membuat sejumlah data kembali lewat suatu model dan seterusnya membentuk suatu siklus. Siklus ini oleh John Burch disebut dengan siklus informasi (information cycle). Siklus ini disebut juga dengan siklus pengolahan data (data processing cycles).

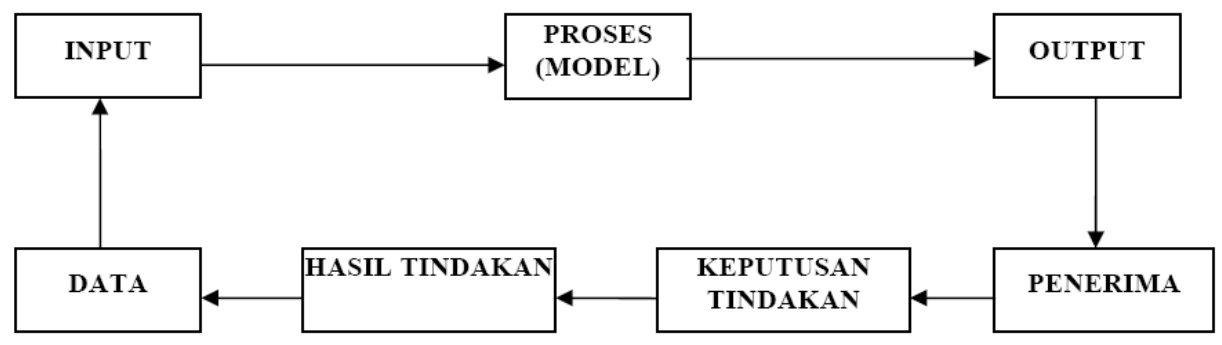

Gambar 2.1 Siklus Informasi

\section{Konsep Dasar Sistem Informasi}

Jogiyanto (2009) mendefinisikan sistem informasi sebagai berikut : "Sistem informasi adalah suatu sistem didalam suatu organisasi yang mempertemukan kebutuhan pengolahan transaksi 
harian, mendukung operasi, bersifat manajerial dan kegiatan strategi dari suatu organisasi dan menyediakan pihak luar tertentu dengan laporan-laporan yang diperlukan".

Organisasi menggunakan sistem informasi untuk mengolah transaksitransaksi, mengurangi biaya dan menghasilkan pendapatan sebagai salah satu produk pelayanan mereka. Perusahaan menggunakan sistem informasi untuk mempertahankan persediaan pada tingkat paling rendah agar konsisten dengan jenis barang yang tersedia. Sebagian besar sistem informasi berlandaskan komputer terdapat didalam suatu organisasi dalam berbagai jenis. Anggota organisasi adalah pemakai informasi yang dihasilkan sistem tersebut termasuk manajer yang bertanggung atas pengalokasian sumber daya untuk pengembangan dan pengoperasian perusahaan.

\section{Konsep Dasar Analisa Sistem}

Jogiyanto (2009) mendefinisikan analisa sistem sebagai berikut : "Analisa sistem adalah penguraian suatu sistem informasi yang utuh kedalam bagian komponenya yang bertujuan untuk mengidentifikasikan dan mengevaluasi permasalahan, kesempatan, hambatan yang terjadi dan menentukan kebutuhan sehingga dapat diusulkan perbaikanya".

\section{Konsep Dasar Analisa dan Perancangan Berorientasi Objek}

Munawar (2005) mengungkapkan : "UML (Unified Modelling Language) adalah salah satu alat bantu yang sangat handal di dunia pengembangan sistem yang berorientasi obyek". Hal ini disebabkan karena UML menyediakan bahasa pemodelan visual yang memungkinkan bagi pengembang sistem untuk membuat cetak biru (blue print) atas visi mereka dalam bentuk baku, mudah dimengerti serta dilengkapi dengan mekanisme yang efektif untuk berbagi (sharing) dan mengkomunikasikan rancangan mereka dengan yang lain.

\section{Konsep Dasar Akuntansi}

\section{Pengertian Akuntansi}

Horngren, Harrison (2007) mendefinisikan akuntansi sebagai berikut : "Akuntansi adalah sistem informasi yang mengukur aktivitas bisnis, memproses data menjadi laporan, dan mengakomodasikan hasilnya kepada para pengambil keputusan". Accounting Principle Board (APB) mendefinisikan akuntansi sebagai berikut : "Akuntansi adalah suatu kegiatan jasa. Fungsinya adalah memberikan informasi kuantitatif, umumnya dalam ukuran uang, mengenai suatu badan ekonomo yang dimaksudkan untuk digunakan dalam pengambilan keputusan ekonomi sebagai dasar memilih di antara beberapa alternativ".

\section{Pengertian Sistem Akuntansi}

Menurut Mulyadi (2013) Sistem akuntansi adalah organisasi formulir, catatan dan laporan yang dikoordinasi sedemikian rupa untuk menyediakan informasi keuangan yang dibutuhkan oleh manajemen dalam pengelolaan. Menurut Nugroho, Erwin Aryo (2009) mengemukakan bahwa : "Sistem akuntansi merupakan suatu alat yang dipakai untuk mengorganisir atau menyusun ,mengumpulkan, dan mengikhtiarkan keterangan-keterangan yang menyangkut seluruh transaksi perusahaan, dimana para pegawai, kegiatan-kegiatan perusahaan, bahanbahan dan mesin-mesin dapat dipadukan sedemikian rupa sehingga pengawasan dapat dijalankan sebaik-baiknya."

\section{Pengertian Sistem Informasi Akuntansi}

Menurut Susanto (2013) sistem informasi akuntansi sebagai berikut: "Kumpulan atau group dari sub sistem / bagian / komponen apapun baik phisik atau non phisik yang saling berhubungan satu sama lain dan bekerja sama secara harmonis untuk mengolah data transaksi yang berkaitan dengan masalah keuangan menjadi informasi keuangan“. Jogiyanto (2009) mendefinisikan sistem informasi akuntansi sebagai berikut : "Sistem Informasi Akuntansi adalah suatu komponen organisasi yang mengumpulkan, mengklasifikasikan, 
memproses, menganalisis, mengkomunikasikan informasi pengambilan keputusan dengan orientasi finansial yang relevan bagi pihak - pihak luar dan pihak - pihak dalam perusahaan (secara prinsip adalah manajemen)". Jerry, dkk(2007) mendefinisikan sistem informasi akuntansi sebagai berikut : "Sistem informasi akuntansi adalah sistem yang mengumpulkan dan memproses transaksi-transaksi data dan menyampaikan informasi keuangan kepada pihak-pihak tertentu".

\section{Pengertian Jurnal}

Menurut Mulyadi (2013) jurnal merupakan catatan akuntansi permanen yang pertama, yang digunakan untuk mencatat transaksi keuangan perusahaan. Karena jurnal merupakan catatan akuntansi yang pertama diselenggarakandalam proses akuntansi, maka dalam sistem akuntansi, jurnal harus dirancangsedemikian rupa sehingga tidak akan terjadi satu transaksi pun yang tidak dicatat.

Jurnal terbagi menjadi 2 yaitu Jurnal Umum dan Jurnal Khusus. Jurnalumum digunakan apabila jenis transaksi perusahaan masih sedikit, untukmenampung transaksi penjualan, pembelian, penerimaan dan pengeluaran kas,depresiasi aset, dan lainnya.

\section{Pengertian Penjualan}

Menurut Puspitawati (2011) penjualan merupakan aktivitas memperjualbelikan barang dan jasa kepada kosumen. Sulistiyowati (2010) mendefinisikan penjualan adalah pendapatan yang berasal dari penjualan produkperusahaan, disajikan setelah dikurangi potongan penjualan danretur penjualan. Dari pengertian tersebut mengenai penjualan, maka dapat disimpulkan bahwa penjualan adalah salah satu aktivitas rutin yang dijalani oleh setiap perusahaan dalam memperjualbelikan barang dan jasanya, yangtujuannya untuk memperoleh laba dan untuk membuat perusahaan tersebut tambah berkembang.

\section{Metodologi Penelitian}

\section{Metode Pengumpulan Data}

Metode pengumpulan data yaitu mendapatkan data dengan cara :

1. Observasi

Kegiatan ini dilakukan untuk mengumpulkan data dengan cara pengamatan langsung dengan hal-hal yang berkaitan dengan sistem informasi penjualan yang sekaligus bahan masukan untuk penulisan penelitian ini.

2. Wawancara

Mempelajari dan menganalisa sistem yang sedang berjalan sertamendapatkan data langsung dari sumbernya dengan tanya jawab danwawancara diharapkan informasi yang diperoleh benar-benar dapatdipertanggungjawabkan atas pertanyaan yang diajukan.

3. Studi Kepustakaan

Dilakukan dengan cara membaca buku-buku yang berkaitan dengan masalah sistem informasi penjualan. Penelitian kepustakaan ini secara teoritis sangat membantu di dalam pembuatan penelitian ini.

\section{Analisa Sistem}

Kegiatan yang dilakukan pada tahap ini yaitu menganalisa sistem yang ada dengan mempelajari dan mengetahui apa yang akan dikerakan sistem yang ada, menspesifikasi sistem yaitu menspesifikasi masukan yang digunakan, database yang ada, proses yang dilakukan dan keluaran yang dihasilkan sistem adalah metode berorientasi obyek.

Produk yang dihasilkan berupa model dari sistem yang ada, dan alat-alat yang digunakan yaitu :

1. UseCase Diagram 
Use case diagram digunakan untuk menjelaskanmanfaat sistem jika dilihat menurut pendangan orang yang berada di luar sistem atau actor.

2. UseCaseDescription

Use case description digunakan untuk mendeskripsikan secara rincimengenai Use Case Diagram.

3. ActivityDiagram

Activitydiagram digunakan untuk memodelkan alur kerja atau workflow sebuah proses bisnis dan urutan aktifitas didalam suatu proses.

\section{Metode Rancangan Sistem}

Tahap perancangan sistem adalah merancang sistem secara rinci dan mendetail berdasarkan hasil analisa sistem yang ada. Sehingga menghasilkan sistem yang baru dengan disertai rancangan database dan spesifikasi program.

Alat-alat yang digunakan pada tahap perancangan sistem ini sama dengan pada tahap analisa sistem manual, ditambah dengan beberapa alat yaitu :

1. Entity Relational Diagram (ERD)

Entity relational diagram digunakan untuk menggambarkan hubungan antara data storage yang ada dalam diagram arus data.

2. Logical Record Structure (LRS)

Logical record structure berasal dari setiap entity yang diubah ke dalam bentuk sebuah kotak dengan nama entity berada di luar kotak dan atribut berada di dalam kotak.

3. Normalisasi

Normalisasi digunakan untuk mengorganisasikan file dengan menghilangkan grup elemen yang berulang atau sebuah langkah proses untuk menyederhanakan hubungan elemen data di dalam record.

4. Spesifikasi Basis Data

Spesifikasi Basis Data digunakan untuk menjelaskan tipe data yang ada pada model konseptual secara terperinci.

5. SequenceDiagram

Sequencediagram menggambarkan interaksi antar obyek di dalam dan di sekitar sistem (termasuk pengguna, display, dan sebagainya) berupa message yang digambarkan terhadap waktu. Sequencediagram terdiri atas dimensi vertikal (waktu) dan dimensi horizontal (obyek-obyek yang terkait).

6. ClassDiagram

Classdiagram membantu dalam visualisasi struktur kelas-kelas dari suatu sistem dan hubungan antar kelas (inheritance, aggregation, dan association) dan penjelasan detail tiap kelas (method, function, behaviour, attribute, dan property data).

\section{Hasil dan Pembahasan}

\section{Rancangan Basis Data}

Urutan Kegiatan dalam merancang basis data sebagaimana disajikan dibawah ini adalah :

1. UseCase Diagram

Dalam fungsi Master, staf dapat melakukan entrydata barang, entry data customer, entry data rekening. 


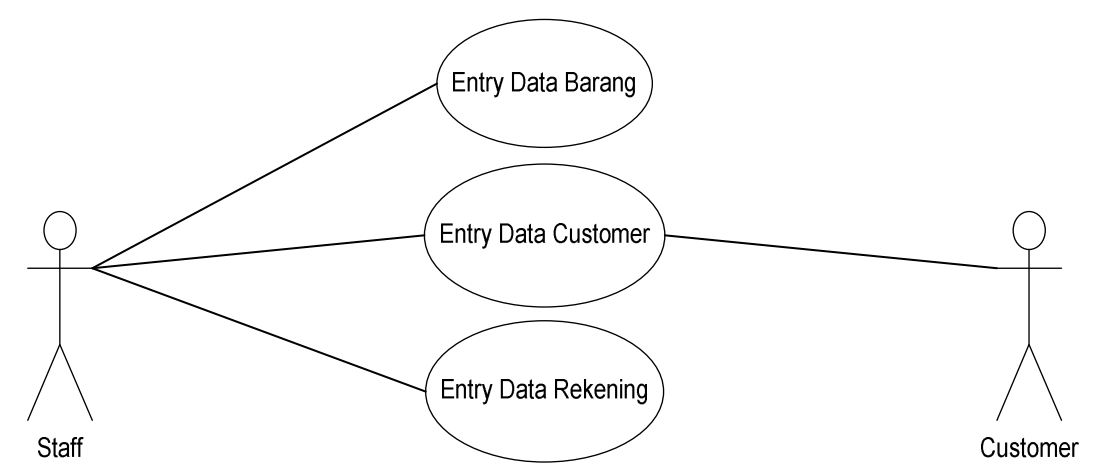

Gambar 2. Use Case Diagram Master

Dalam fungsi Transaksi, staf dapat melakukan pencetakan surat penawaran harga, entry pesanan, pencetakan surat tanda terima barang, pencetakan invoice, pencetakan kwitansi, entry retur.

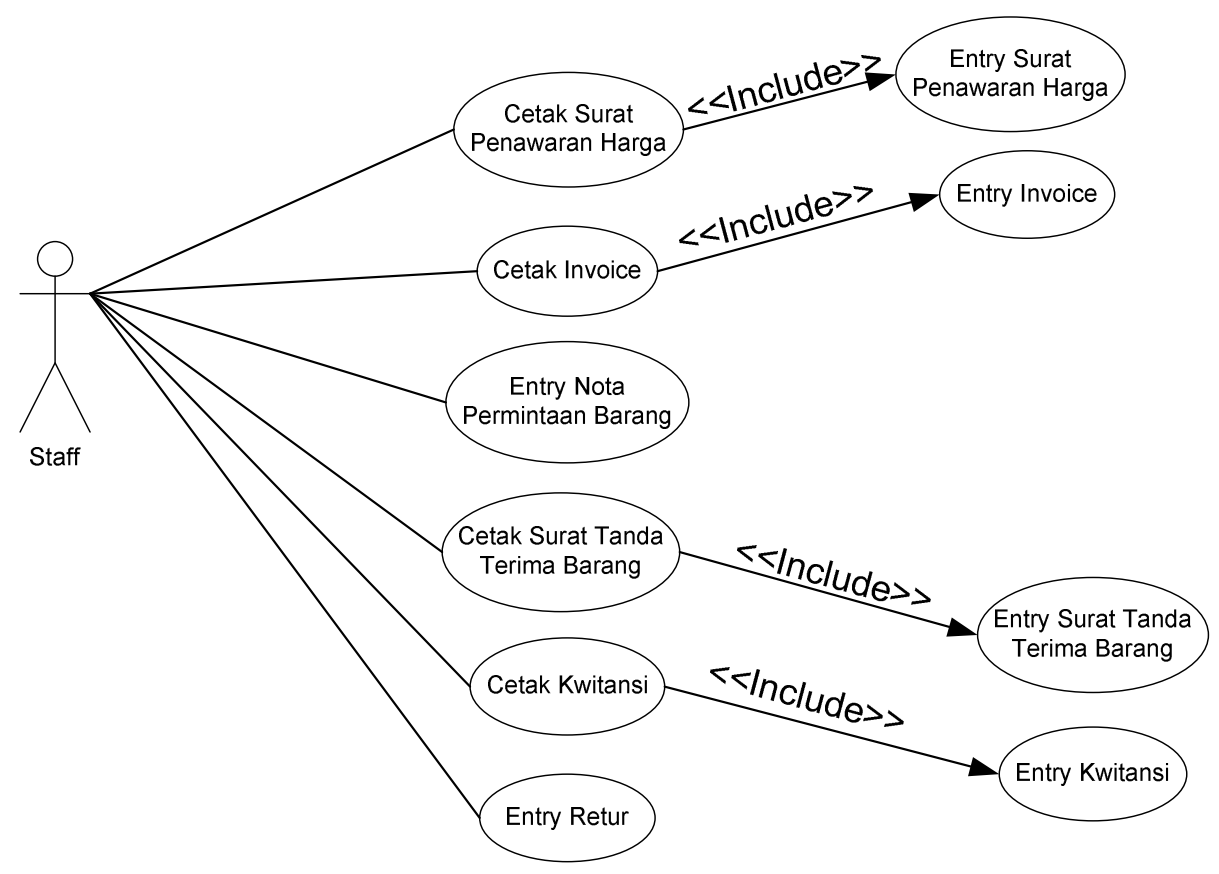

\section{Gambar 3. Use Case Diagram Transaksi}

Dalam fungsi Laporan, staf dapat melakukan pencetakan laporan retur, pencetakan laporan penjualan, pencetakan laporan penerimaan kas, dan pencetakan laporan jurnal umum. 


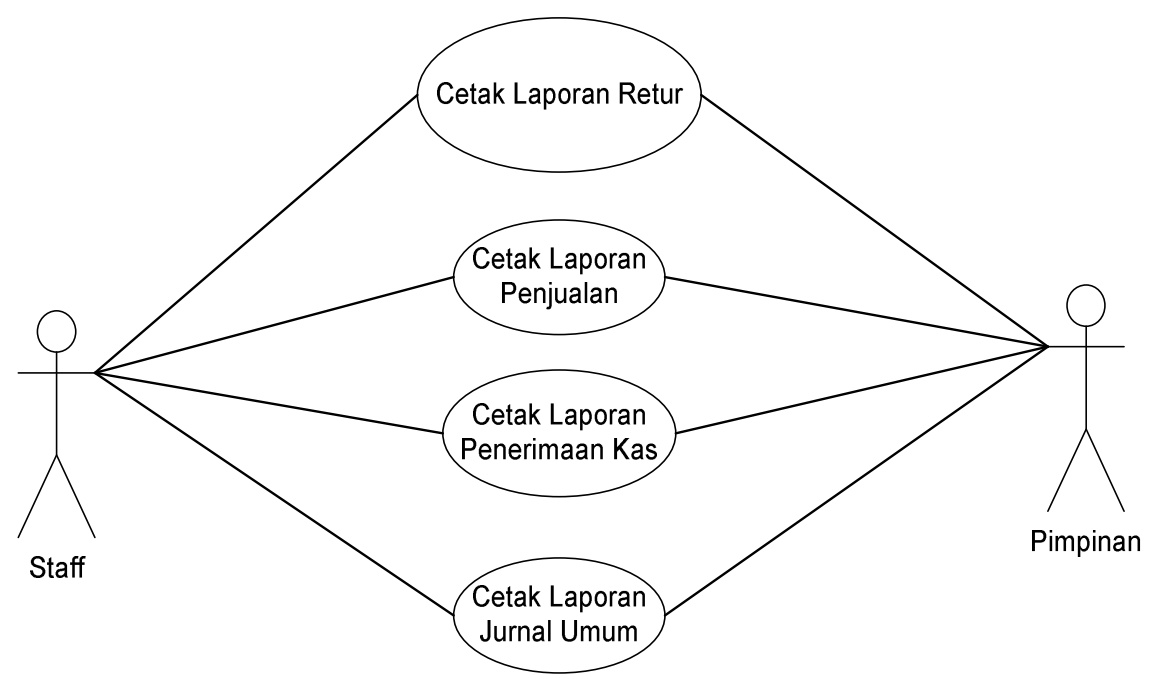

Gambar 4. Use Case Diagram Laporan

2. Entity Relationalship Diagram (ERD)

Entity Relationalship Diagram(ERD) memperlihatkan hubungan antar simpanan data dengan entitas yang digambarkan. 


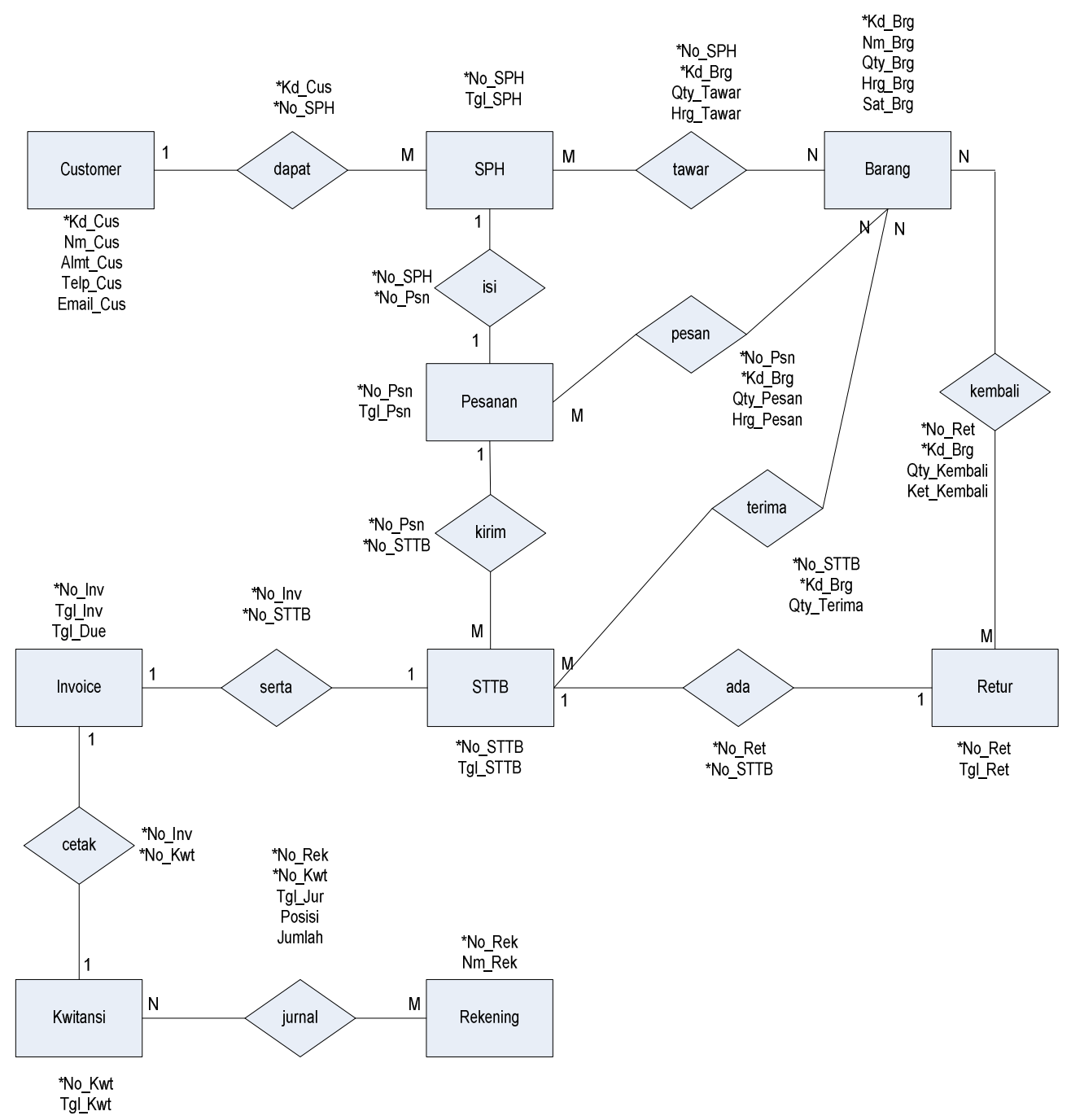

Gambar 5. Entity Relationalship Diagram(ERD)

3. Struktur Tampilan

Struktur tampilan menampilkan menu dan sub menu yang ada pada aplikasi, sebagai berikut : 


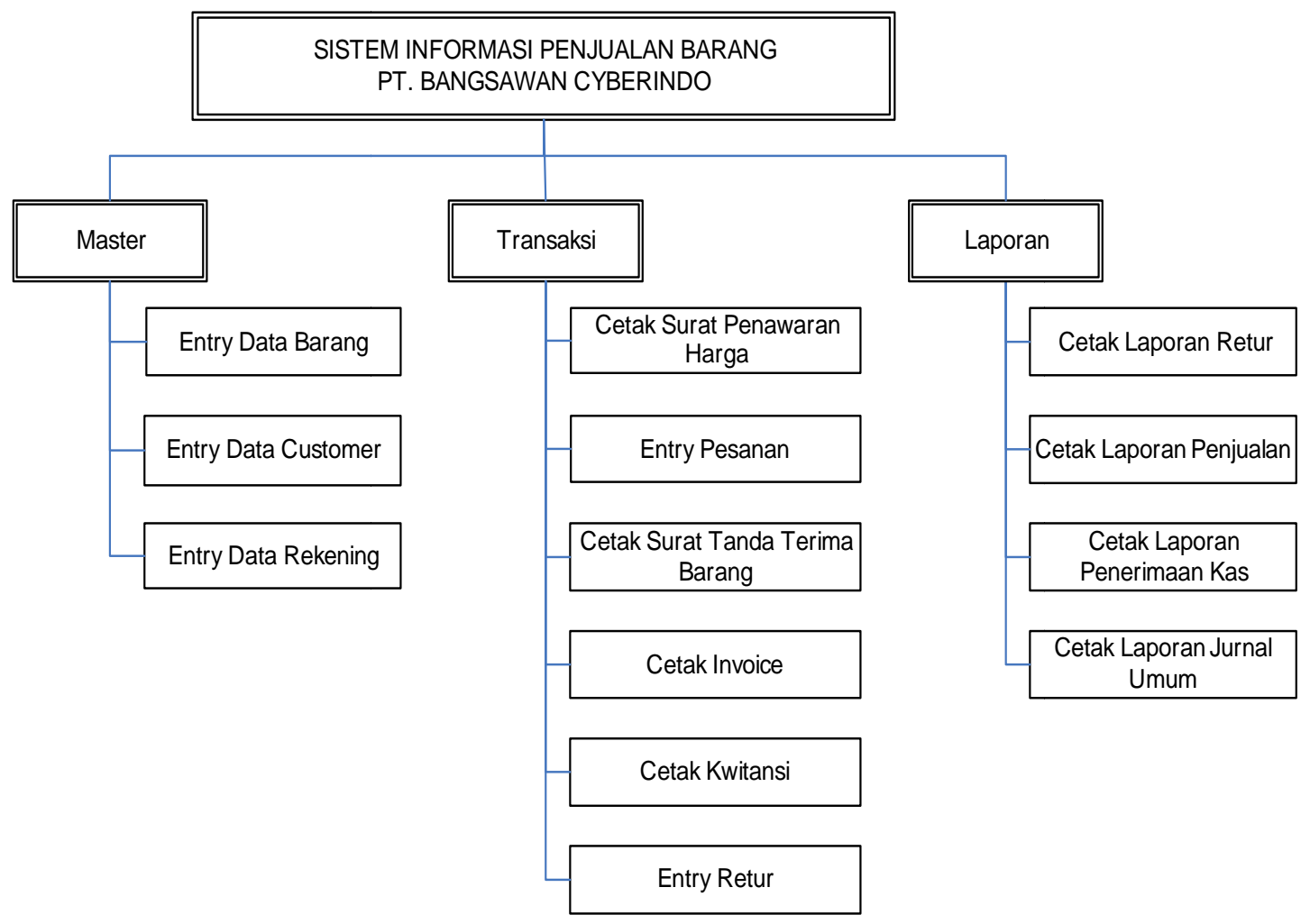

Gambar 6. Struktur Tampilan

4. Rancangan Layar

a) Rancangan Layar Entry Data Customer

Rancangan layar entry data customer merupakan tampilan untuk menambah dan mengedit data customer, sebagai berikut :

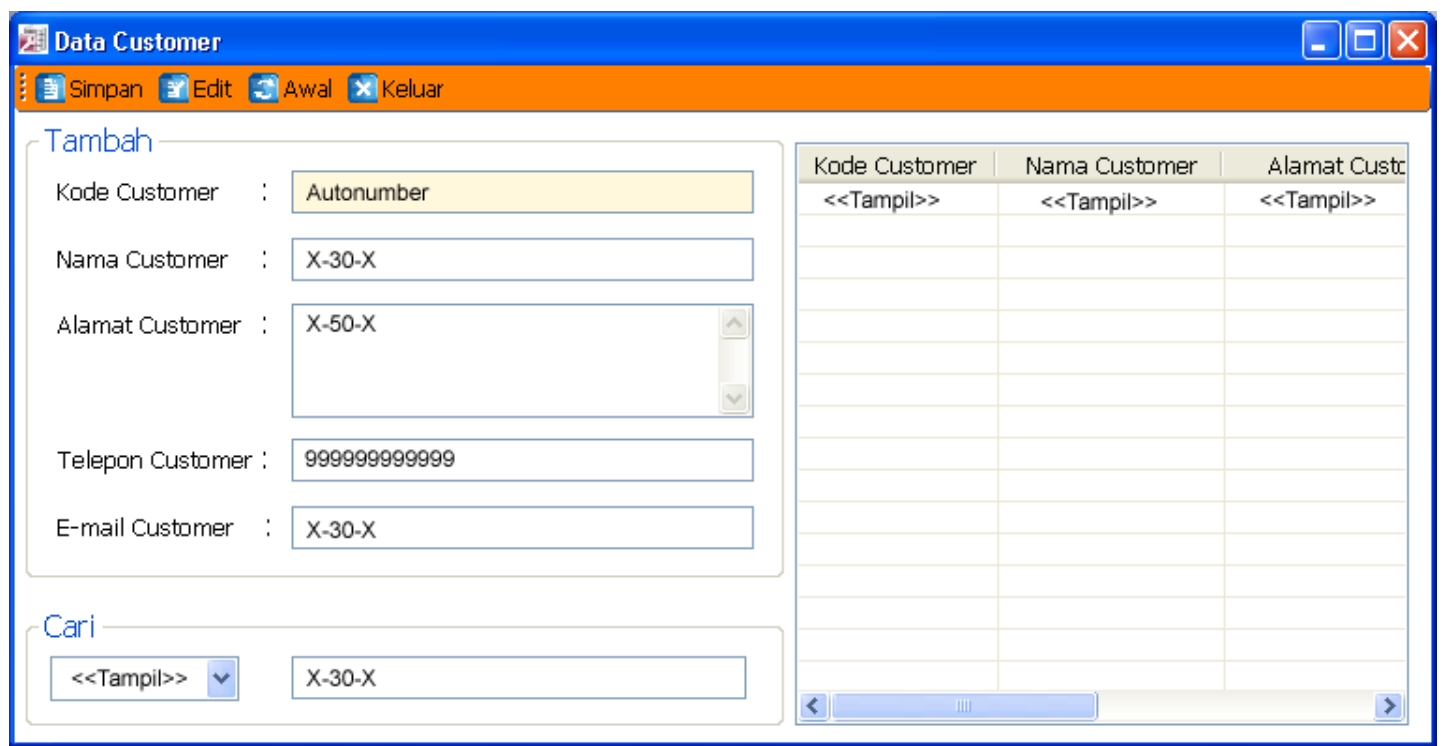

Gambar 7. Rancangan Layar Entry Data Customer 
b) Sequence Diagram Entry Data Customer

Sequence diagram entry data customer menggambarkan interaksi dan komunikasi antar objek dalam data customer.

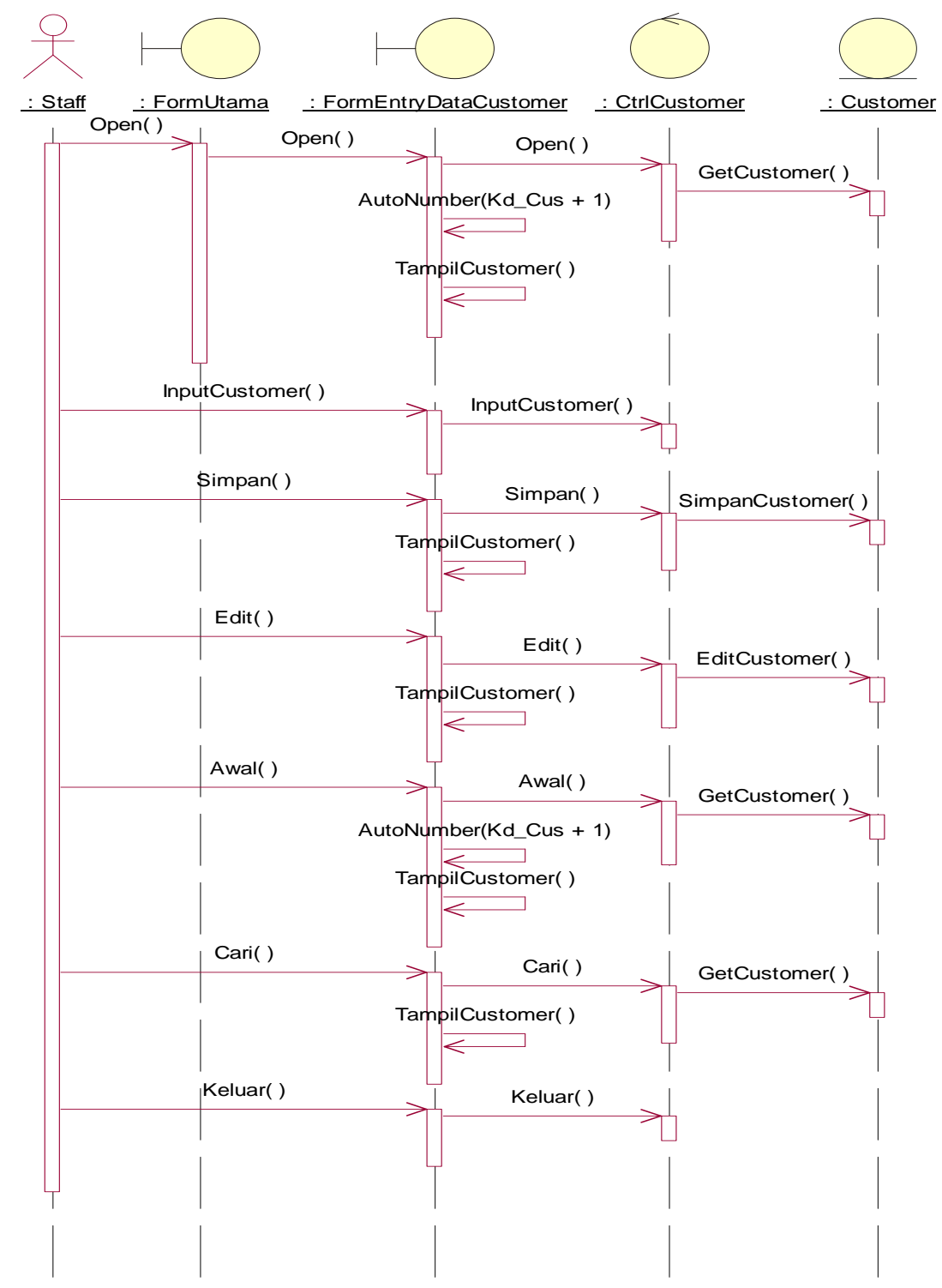

Gambar 8. Sequence Diagram Entry Data Customer 
c) EntityClass Diagram

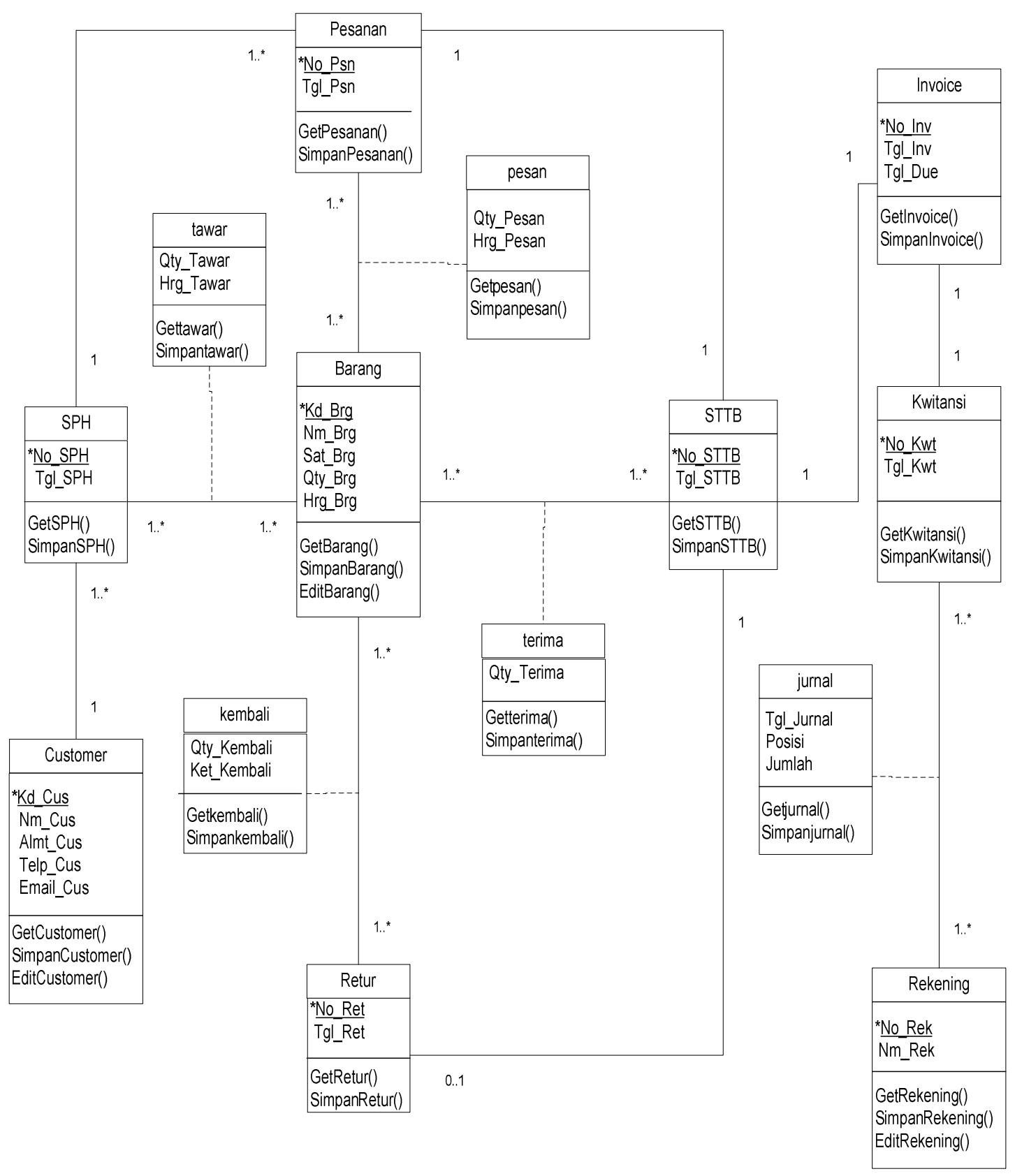

Gambar 9. Entity Class Diagram

\section{Simpulan dan Saran}

Hasil penelitian mengenai Rancang Bangun Sistem Informasi Penjualan Barang dengan Metodologi Berorientasi Obyek : Studi Kasus PT. Bangsawan Cyberindo, penulis menyimpulkan : 
1. Sistem komputerisasi sangat mendukung proses kerja seperti penyimpanan data sehingga dengan mudah dapat memberikan informasi yang dibutuhkan oleh staf penjualan pada saat dibutuhkan.

2. Dengan adanya sistem informasi ini akan membantu staf dalam proses transaksi penjualan barang karena pencatatan tidak perlu lagi dilakukan secara manual sehingga dapat dilakukan cepat, dan akurat.

3. Penyimpanan data dalam database memudahkan penyimpanan, pencarian, dan pemeliharaan data, sehingga tidak perlu lagi menyimpan data dalam media kertas yang mudah hilang dan rusak seperti pada sistem manual.

4. Sistem komputerisasi dapat meminimalkan kesalahan - kesalahan seperti human error.

Dan penulis menyarankan untuk membantu mengatasi masalah yang ada saat ini:

1. Perlu adanya pelatihan user yang akan menggunakan sistem informasi ini, supaya mereka mengetahui bagaiman cara menggunakan dan perawatan sistem informasi ini.

2. Dilakukan back - up secara berkala terhadap data - data yang penting untuk mengantisipasi keadaan yang tidak diinginkan seperti kehilangan data atau kerusakan data.

3. Perlu dilakukan maintenance secara rutin untuk menghidari kesalahan - kesalahan pada sistem ini.

4. Pengecekan terhadap kebenaran data yang masuk ke dalam sistem.

\section{Daftar Pustaka}

Horngren, Harrison. (2007). Akuntansi. Jakarta : Erlangga.

Jogiyanto. (2009). Analisis \& Design. Yogyakarta : C.V Andi Offset.

Mulyadi. (2013). Sistem Akuntansi. Edisi Kelima. Yogyakarta: Salemba Empat.

Munawar. (2005). Pemodelan Visual dengan UML. Edisi 1. Yogyakarta : Graha Ilmu.

Mulyanto. (2009). Sistem Informasi Konsep dan Aplikasi.Yogyakarta. Pustaka Pelajar.

Nugroho, E.A. (2009). Evaluasi Sistem Penerimaan Kas dan Pengeluaran Kas. Universitas Sebelas Maret.

Prasetyo, D.D. (2008). Pemrograman Aplikasi dengan Visual Basic .NET 2005 dan MS Access. Jakarta : Elex Media Komputindo.

Puspitawati,A. (2011). Sistem Informasi Akuntansi. Yogyakarta: Graha Ilmu.

Sadeli, M. (2008). 7 Jam Belajar Interaktif Visual Basic 2005 untuk Orang Awam. Jakarta : Maxikom.

Susanto. (2013).Sistem Informasi Akuntansi. Bandung: Lingga Jaya

Sulistyowati. (2010). Panduan Praktis Memahami Analisis Laporan Keuangan. Jakarta: PT Elex Media Komputindo 